\title{
Trichoptera (Insecta) in water hyacinth roots: evaluation of the influence of exotic mussel and environmental factors
}

\author{
Trichoptera (Insecta) em raízes de aguapé: avaliação da influência de mexilhão \\ exótico e fatores ambientais
}

Sandra Francisca Marçal ${ }^{1,2 *}$, Claudia Tasso Callil ${ }^{3}$ and Rogério Conceição Lima dos Santos ${ }^{4}$

1Programa de Pós-graduação em Ciências Ambientais - PPGCA, Universidade de Cuiabá - UNIC, Avenida Beira Rio, 3100, CEP 78065-900, Cuiabá, MT, Brazil

e-mail: sandraabio@gmail.com

${ }^{2}$ Programa de Pós-graduação em Ecologia e Conservação da Biodiversidade - PPGCEB, Universidade Federal de Mato Grosso - UFMT, Cuiabá, MT, Brazil

${ }^{3}$ Laboratório de Ecologia Aquática, Departamento de Biologia e Zoologia, Instituto de Biociências,

Universidade Federal de Mato Grosso - UFMT, CEP 78065-900, Cuiabá, MT, Brazil

e-mail: callil@ufmt.br

${ }^{4}$ Programa de Pós-graduação em Recursos Hídricos, Faculdade de Arquitetura, Engenharia e Tecnologia, Universidade Federal de Mato Grosso - UFMT, Avenida Fernando Corrêa da Costa, 2367, CEP 78060-900, Cuiabá, MT, Brazil e-mail: roger.c.l.santos@gmail.com

\begin{abstract}
Aim: Information on the influence of mussel macrofouling in invertebrate communities usually have the initial assumption of negative interference. Methods: We analyzed this relationship in a community of aquatic invertebrates associated to roots of Eichhornia crassipes in 15 shallow marginal lakes in the Pantanal National Park and surroundings. We sampled quadrants of floating vegetation, identified the aggregate fauna and evaluated the density effect of Limnoperna fortunei, as well as abiotic factors of the Trichoptera community using ordinances and multivariate regressions. Results: We found no significant relationship between the abundance of mussels on the macrophytes and the Trichoptera larvae. However, we observed an interference of oxygen on the structure and density of genera. The composition and abundance of the phytophylous caddisfly community is influenced by the depth and the concentration of oxygen dissolved in the marginal regions of the lakes. Conclusions: We suggest that the absence of the effects of the assessed L. fortunei in the community is related to the 'biotic resistance', in which the phytophylous caddisfly demonstrated adaptation to an environment characterized by hypoxic conditions in the dry season. L. fortunei was limited by the depth and reduction of oxygen, presenting lower density in lakes with such characteristics.
\end{abstract}

Keywords: aquatic invertebrates; bio invaders; golden mussel; wetlands.

Resumo: Objetivo: Informaçóes sobre a influência de macroaglomerados de mexilhão em comunidades de invertebrados geralmente apresentam o pressuposto inicial de interferência negativa. Métodos: Analisamos essa relação em uma comunidade de invertebrados aquáticos associados a raízes de Eichhornia crassipes em 15 lagoas marginais rasas, no Parque Nacional do Pantanal e áreas adjacentes. Amostramos quadrantes da vegetação flutuante, identificamos a fauna associada e avaliamos o efeito da abundância de Limnoperna fortunei e fatores abióticos sobre a comunidade de Trichoptera, utilizando ordenaçōes e regressóes multivariadas. Resultados: Não encontramos relação significativa da abundância de mexilhão nas macrófitas sob as larvas Trichoptera. Entretanto, observamos a interferência do oxigênio na estrutura e abundância dos gêneros. A composição e abundância da comunidade de tricópteros fitófilos é influenciada pela profundidade e oxigênio dissolvido na regiáo marginal das lagoas. Conclusóes: Sugerimos que a ausência de efeitos de $L$. fortunei na comunidade avaliada está relacionada com a 'resistência biótica' na qual os tricópteros fitófilos demonstraram adaptação ao ambiente caracterizado por condiçóes de hipoxia na estação seca, enquanto que $L$. fortunei foi limitado pela profundidade e redução de oxigênio, apresentando menores densidades em lagoas com essas características.

Palavras-chave: invertebrados aquáticos; bioinvasores; mexilhão dourado; áreas úmidas. 


\section{Introduction}

The Caddisfly is a diverse group of insects with immature aquatic stages. They normally occur in streams with cooler oxygenated water (Wiggins, 2000; Bispo et al., 2006), but can also thrive in floodplains (Pescador et al., 1995) mainly in association with other aquatic plants. The water hyacinth roots (Eichhornia crassipes Mart. Solms-Laubach), are a special biotope that harbors a complex aquatic community, comprised of periphyton, zooplankton and invertebrates ("interrhizon") (Ohtaka et al., 2011). This microhabitat includes a diversified fauna of insects (Poi de Neiff \& Carignan, 1997; RochaRamírez et al., 2007; Silva \& Henry, 2013) and the Trichoptera is a special element related to the trophic chain and ecological process (Wiggins, 2000).

The exotic bivalve Limnoperna fortunei (Dunker 1857) (Bivalvia, Mytilidae) also lives in association with macrophytes in the aquatic system of Pantanal. Their larvae are fixed and develop in floating mats of water hyacinths (E. crassipes, Eichhornia azurea (Swartz) Kunth) (Marçal \& Callil, 2008), which act as dispersal agents floating downriver or driven by wind (Pott et al., 2011).The high reproduction rate and clustering behavior gives this bivalve a high capacity for installation and accelerated population growth (Boltovskoy et al., 2006). The presence of factors limiting the invasion and establishment of populations, which are related to limnological and hydrological characteristics of rivers (Oliveira et al., 2011; Boltovskoy, 2015), as well as chemical, physical, and biological control mechanisms (Soares et al., 2009; Boltovskoy, 2015) have been investigated. But after more than 20 years of study, effective solutions to limit the spread of $L$. fortune $i$ larvae have not been found and the species is still likely to invade new Brazilian watersheds.

Since the introduction of L. fortunei in South America, the understanding of interactions between particular communities or populations (Sax et al., 2005) has become a challenge to researchers, as structural and functional alterations have been demonstrated (Mansur et al., 2003; Brugnoli et al., 2005). The filtering activity of $L$. fortunei reduces the biomass of phytoplankton, periphyton and zooplankton populations, which causes a cascading effect in the aquatic ecosystem (Brugnoli et al., 2005). Studies predicting the deleterious effect of the golden mussel on the community of aquatic invertebrates, concluded that some groups of typically opportunistic invertebrates (Hirudinea,
Oligochaeta, Nematoda and Gastropoda) were favored due to the increase of structural complexity by macrofouling of L. fortunei (Darrigran et al., 1998; Sylvester et al., 2007a; Darrigran \& Damborenea, 2009, 2011; Burlakova et al., 2012). The facilitative effects of exotic mussels on benthic species are strongly positively related to its density (Bruno et al., 2005), and dense populations of golden mussels alter the aquatic trophic structure of taxa considered resistant to changes in the environment. However, the effects of this invasive species is still little understood, above all, in habitats, groups of invertebrates/vertebrates and peculiar ecosystems. Biological processes emphasizing interactions between native-exotic species, have been approached for further discussion related to "biotic-resistance" (Simberloff \& Von Holle, 1999), once the increased biotic and ecological resistance to ecosystem is a disadvantage to the establishment of invasive species (Espinola \& Júlio Junior, 2007). Given this context, the evaluation of the golden mussels effect on the structure of populations and specific communities has great relevance.

This study aimed to evaluate the influenced of two predictors in the structure of Trichoptera phytophylous: i) abundance of $L$. fortunei and ii) limnological variables in floodplain lakes in the Paraguay river in the dry season, in addition to presenting new data about the composition, richness, abundance and density of Trichoptera associated with macrophytes.

\section{Material and Methods}

This study was carried out in fifteen marginal lakes to the Upper Paraguay River, between the Pantanal National Park and a Private Reserve, RPPN Acurizal, which are protected areas located on southwest part of Mato Grosso state, at the border of Brazil and Bolivia (Figure 1). The Paraguay River begins in the Chapada do Parecis plateau, becoming a tributary of the Paraná River which in turn, empties into the La Plata basin that extends over an area of $3,100,000 \mathrm{~km}^{2}$. The climate is warm with an average temperature of $25^{\circ} \mathrm{C}$, humidity of about $77 \%$, and average annual rainfall of $1,070 \mathrm{~mm}$, which is more intense from November to March -known regionally by flood periods- and dry season from April to October, considered the draining and dry periods (Oliveira et al., 2006). In the dry season, the floodplain lakes of the Paraguay River may present depths of up to 2 meters (Marchese et al., 2005) and may be connected to the main channel permanently or only during flood 


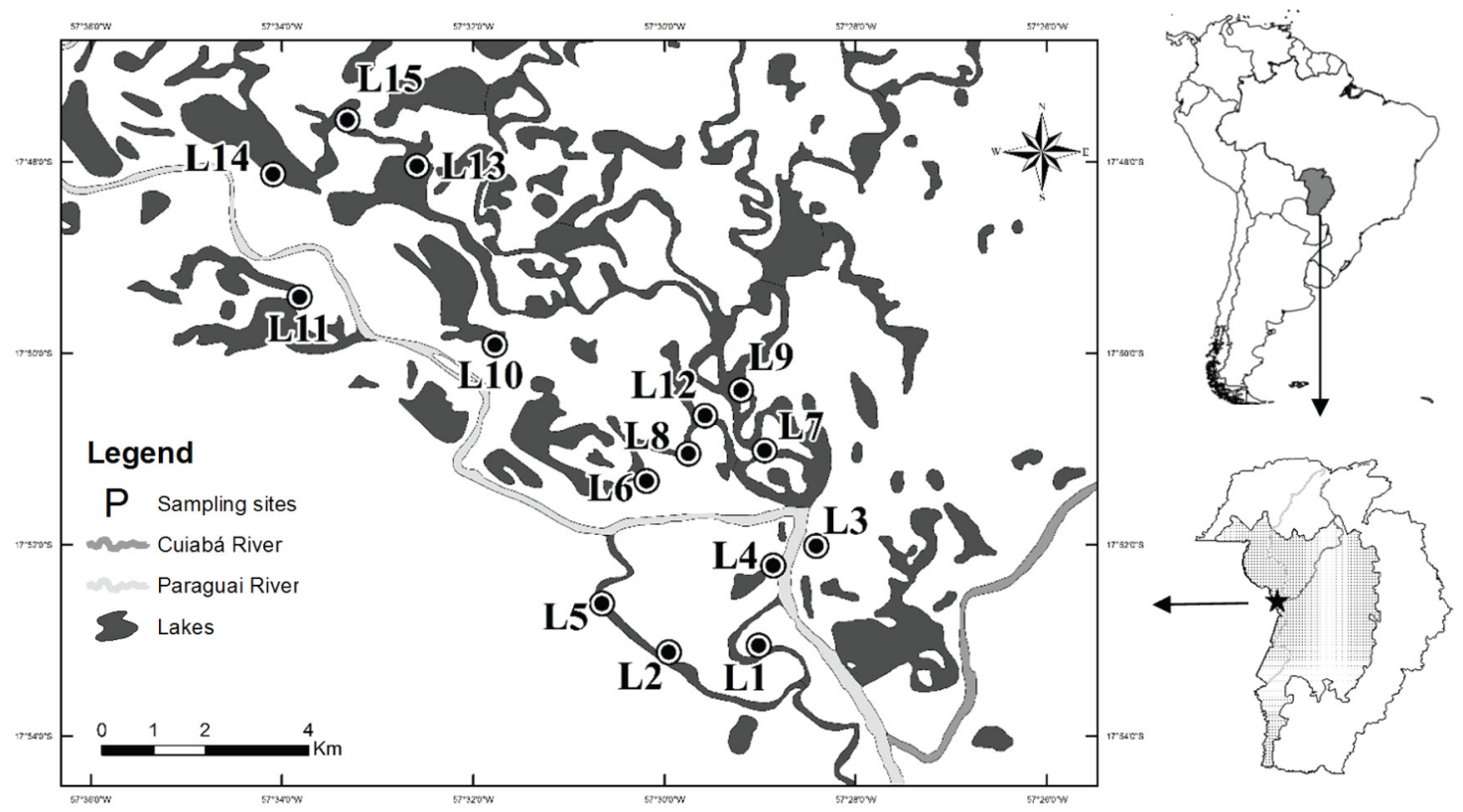

Figure 1. Map of location of the 15 marginal lakes along Paraguay River, on southeast Upper Basin Paraguay (BAP), in southwest part of MT State, Brazil, sampled in September of 2005.

peaks (= oxbows shallow lakes). These environments usually present low concentrations of dissolved oxygen, high organic matter content, and stands of floating macrophytes in different stages of dominance, including E. crassipes (Wantzen et al., 2005).

The sampling was conducted in a single campaign in the dry season (in September 2005) in order to avoid interference from disturbances caused by rain in invertebrate animals. The physicochemical variables were determined in each lake (in triplicate) using Secchi disk (depth, transparency) and sensors of each of the parameters (temperature, $\mathrm{pH}$, dissolved oxygen and electrical conductivity). Three samples of the monospecific marginal stands of floating vegetation were sampled from a $25 \times 25 \mathrm{~cm}$ square using pruning shears, the total area collected was of $0.1875 \mathrm{~m}^{2}$ per lake. In the laboratory, the plant's root mass was washed in $2 \mathrm{~mm}, 1 \mathrm{~mm}$ and $0.25 \mathrm{~mm}$ mesh, and the resulting part retained in the last sieves was preserved in 70\% alcohol. The roots of the plants were sun-dried, placed in an oven at $60{ }^{\circ} \mathrm{C}$ (about 72 hours), and then weighed to estimate the biomass in grams of dry weight.

The larvae of Trichoptera were screened and identified under a stereoscopic microscope, as described by Domínguez \& Fernández (2009). Considering the lake as a sampling unit, the average abundance of Trichoptera was obtained from the replicates. Based on the biomass of roots on the sampled area, the density of Trichoptera larvae and L. fortune $i$ were expressed in number of individuals per $100 \mathrm{~g}$ of root dry weight (ind. $100 \mathrm{~g}^{-1} \mathrm{DW}$ ) and individuals per square meter (ind. $\mathrm{m}^{-2}$ ).

Before performing statistical tests, the relationship between physical and chemical variables were evaluated through the Spearman Correlation and the variables which presented values above 0.5 (rs $>0.5 ;{ }^{*} \mathrm{p}<0.05 ;{ }^{* *} \mathrm{p}<0.01$ ). The $\mathrm{pH}$ was correlated to the conductivity $\left(0.657^{* *}\right)$; the depth was correlated to the dissolved oxygen $\left(0.6385^{* *}\right)$ and water temperature $\left(0.611^{*}\right)$; the later was also correlated to the conductivity $\left(-0.574^{*}\right)$. Due to covariance with other variables, the temperature was not considered as an environmental predictor. A Principal Component Analysis (PCA) was used to summarize the physical and chemical characteristics of water in the 15 lakes-from the average values-and use the graphical tool screen plot to retain only those components that explained most of the variation of the data, as suggested by Gotelli \& Ellison (2010) (Figure 2).

The relationship between the average abundance of genera, average abundance of Trichoptera and L. fortunei were tested amongst themselves and in relation to the physicochemical variables through a Spearman's correlation ( $r s>0.5 ; \mathrm{p}<0.05 ; \mathrm{p}<0.01)$, after being tested for normality (Shapiro-Wilks; $\alpha=0.05$ ) and homocedasticity (Levene; $\alpha=0.05$ ), and transformed $(\log (x+1)$. We ordered the average composition and abundance of Trichoptera genera 


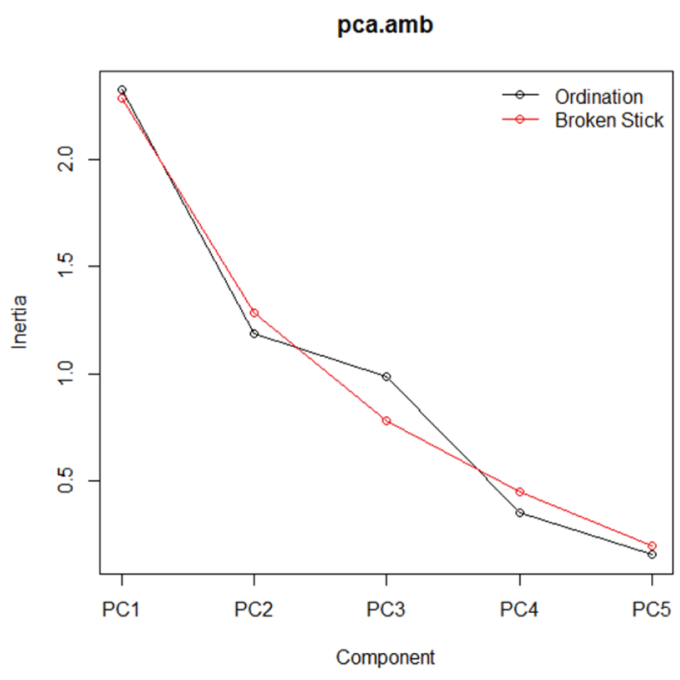

Figure 2. Result of the Principal Components Analysis (PCA) showing the scree plot for the physiochemical variables in the 15 marginal lakes along to the Paraguay River, MT.

through the PCoA (Principal Coordinate Analysis) with the Bray-Curtis association index (Legendre \& Legendre, 1998). For this purpose, the abundance of each taxon was transformed in $\log (x+1)$, to reduce a heterocedasticity. The relationship between the Trichoptera community (PCoA axes), physiochemical variables (components of the PCA), and abundance of L. fortunei was assessed by multivariate inferential analysis by Generalized Linear Model.

The relationship between the Trichoptera community and the physicochemical variables was analyzed using Generalized Linear Models between the axes of PCoA, PCA and the abundance of L. fortunei. $(\mathrm{p}<0.05)$. We used the models (i) average abundance of Trichoptera (PCoA) in relation to environmental variables (PCA) and abundance of L. fortunei, (ii) average abundance of Trichoptera genera in relation to environmental variables (PCA) and abundance of L. fortunei, (iii) average abundance of Trichoptera (PCoA) in relation to environmental variables (PCA) and (iv) average abundance of Trichoptera genera (PCoA) in relations to environmental variables (PCA). The data analysis was conducted by using the program R ( $R$ Development Core Team, 2013) using functions of the vegan package (Oksanen et al., 2013) and descriptive graphics in the SPSS statistics, version 22.

\section{Results}

The 15 marginal lakes sampled were shallow (30 to $98.33 \mathrm{~cm}$ ) with low dissolved oxygen saturation (1.18 to $2.20 \mathrm{mg} . \mathrm{1}^{-1}$ ) and variable transparency $(5.67$ to $33.33 \mathrm{~cm})$. The $\mathrm{pH}$ values tended to neutrality ( 6.3 to 7.28 ); the conductivity showed short variation between 46.27 to $90.4 \mu \mathrm{S} . \mathrm{cm}^{-1}$ and the water temperature ranged from 19.4 to $26.1^{\circ} \mathrm{C}$ (occasional cold fronts) (Table 1).

The PCA conducted with the environmental variables extracted two axes which explained $70.16 \%$ of the total data variation (Figure 3). The first axes of PCA have captured $46.42 \%$ of variance of the data and were negatively related with conductivity and positively with dissolved oxygen. The second component explained $23.74 \%$ of the data variance, was negatively represented by $\mathrm{pH}$ and positively by the transparency of water (Figure $3 \mathrm{~A}$ and $3 \mathrm{~B}$ ).

A total of 4,761 Trichoptera larvae associated with $E$. crassipes roots were sampled, distributed within 13 taxa belonging to the families Hydroptilidae, Leptoceridae, Hydropsychidae and Polycentropodidae (Table 2). The genus Neotrichia sp2 dominated with $>50 \%$ of relative abundance, followed by Polycentropus sp. and Oecetis sp. (>10\%), comprised the three, most of $80 \%$ of the total individuals (Table 2). The genera Flintiella, Smicridea and the morphospecies Hydroptilinae e Leptoceridae were represented by only 1 individual $(0.02 \%)$ of the total (Table 2$)$.

The density of Trichoptera varied from 31.45 to 572 ind. $100 \mathrm{~g}^{-1}$ DW (L8 and L11) and 357.33 to 4,448 ind. $\mathrm{m}^{-2}$ (L3 and L6; respectively). L. fortunei density varied from 3.5 to 548.85 ind. $100 \mathrm{~g}^{-1} \mathrm{DW}$ and 21 to 3,616 ind. $\mathrm{m}^{-2}$ in (L11 and L12; respectively) (Table 3). Ordering the lakes to river gradient (upstream /downstream) we observed that the majority of deeper lakes $( \pm 60$ to $100 \mathrm{~cm})$ are upstream and shallower lakes $( \pm 30$ to $60 \mathrm{~cm})$ are downstream. Some genera of Trichoptera showed pronounced density in the lakes $\left(1,099\right.$ to 4,448 ind. $\left.\mathrm{m}^{-2}\right)$ with lower mean depth in the littoral region (downstream) (Table 3; Figure 4A). These shallower lakes in marginal areas with water hyacinth, totaled about of $70 \%$ of Trichoptera larvae sampled (Figure 4A). Already L. fortunei were more abundant mostly in deeper lakes upstream (1,483 to 3,616 ind. $\mathrm{m}^{-2}$ ) (Table 3).

The PCoA axes explained $>70 \%$ of the variation of community of Trichoptera in composition and abundance data. For the average abundance of 
Table 1. Localization and average values of the physicochemical variables of the water of the 15 marginal lakes along the Paraguay River sampled in September of 2005.

\begin{tabular}{|c|c|c|c|c|c|c|c|}
\hline & Lakes & $\begin{array}{c}\text { Geographical } \\
\text { coordinates }\end{array}$ & $\mathrm{pH}$ & $\begin{array}{c}\mathrm{DO} \\
\left(\mathrm{mg} \cdot \mathrm{L}^{-1}\right)\end{array}$ & $\begin{array}{c}\text { E.C. } \\
\left(\mu \mathrm{S} . \mathrm{cm}^{-1}\right)\end{array}$ & $\begin{array}{l}\text { W.T. } \\
\left({ }^{\circ} \mathrm{C}\right)\end{array}$ & $\begin{array}{c}\text { Transparency } \\
(\mathrm{cm})\end{array}$ \\
\hline L1 & Desprezo & 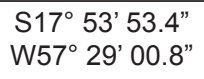 & $7.28 \pm 0.07$ & $1.56 \pm 0.28$ & $81.13 \pm 7.01$ & $20.57 \pm 1.31$ & $10 \pm 0.0$ \\
\hline $\mathbf{L 2}$ & Piuval & $\begin{array}{l}\mathrm{S} 17^{\circ} 53^{\prime} 37.6^{\prime \prime} \\
\text { W57 } \\
9^{\circ} 57.4^{\prime \prime}\end{array}$ & $6.69 \pm 0.2$ & $1.35 \pm 0.03$ & $90.4 \pm 14.18$ & $21 \pm 0.62$ & $38.33 \pm 12.58$ \\
\hline L3 & Caracará & $\begin{array}{l}\mathrm{S} 17^{\circ} 52^{\prime} 50.9^{\prime \prime} \\
\text { W57 } 28^{\prime} 24.8^{\prime \prime}\end{array}$ & $6.51 \pm 0.10$ & $1.26 \pm 0.06$ & $65.17 \pm 0.86$ & $20.13 \pm 0.93$ & $13.33 \pm 5.77$ \\
\hline L4 & Joãozinho & $\begin{array}{l}\mathrm{S} 17^{\circ} 52^{\prime}, 13.2^{\prime \prime} \\
\text { W57 } 28^{\prime} 51.8^{\prime \prime}\end{array}$ & $6.42 \pm 0.14$ & $1.18 \pm 0.11$ & $67.73 \pm 0.40$ & $20.9 \pm 0.96$ & 20.00 \\
\hline L5 & Comprida & $\begin{array}{l}\mathrm{S} 17^{\circ} 52^{\prime} 36.9^{\prime \prime} \\
\text { W57 } \\
0^{\circ} 39.3^{\prime \prime}\end{array}$ & $6.79 \pm 0.30$ & $1.57 \pm 0.07$ & 83.43 & $19.4 \pm 1.30$ & $10 \pm 0.0$ \\
\hline L6 & Cláudia & $\begin{array}{l}\mathrm{S} 17^{\circ} 51^{\prime} 20.1^{\prime \prime} \\
\text { W57 } \\
\end{array}$ & $6.36 \pm 0.14$ & $1.92 \pm 0.22$ & $68.63 \pm 4.09$ & $23.67 \pm 0.25$ & $18.33 \pm 2.89$ \\
\hline L7 & Três Bocas & $\begin{array}{l}\mathrm{S} 17^{\circ} 51^{\prime} 21.1^{\prime \prime} \\
\text { W57 } 27^{\circ} 57^{\circ} .1^{\prime \prime}\end{array}$ & $6.43 \pm 0.05$ & $2.20 \pm 0.27$ & $46.27 \pm 5.25$ & $22.67 \pm 0.23$ & $5.67 \pm 1.15$ \\
\hline L8 & Sandrinha & $\begin{array}{l}\mathrm{S} 17^{\circ} 51^{\prime} 02.9^{\prime \prime} \\
\text { W57 } 27^{\circ} 45.0^{\prime \prime}\end{array}$ & $6.47 \pm 0.08$ & $1.83 \pm 0.19$ & $69.98 \pm 1.35$ & $24.50 \pm 0.44$ & $19.3 \pm 4.4$ \\
\hline L9 & Caracarazinho & $\begin{array}{l}\mathrm{S} 17^{\circ} 50^{\prime} 23.2^{\prime \prime} \\
\text { W57 } 27^{\circ} 12.1^{\prime \prime}\end{array}$ & $6.3 \pm 0.02$ & $1.73 \pm 0.09$ & $55.6 \pm 0.72$ & $25.23 \pm 0.21$ & $11.67 \pm 2.89$ \\
\hline L10 & Inês & $\begin{array}{l}\mathrm{S} 17^{\circ} 49^{\prime} 54.9^{\prime \prime} \\
\text { W57 } 37^{\circ} 46.4^{\prime \prime}\end{array}$ & $6.45 \pm 0.07$ & $1.46 \pm 0.12$ & $71.50 \pm 1.14$ & $25.87 \pm 0.91$ & $20 \pm 0.0$ \\
\hline L11 & Acurizal & $\begin{array}{l}\text { S17 } 47^{\circ} 9^{\prime} 24.8^{\prime \prime} \\
\text { W57 } 33^{\prime} 48.9^{\prime \prime}\end{array}$ & $6.51 \pm 0.06$ & $1.32 \pm 0.16$ & $74.13 \pm 1.40$ & $21.53 \pm 0.81$ & 20.00 \\
\hline L12 & Turco & $\begin{array}{l}\mathrm{S} 17^{\circ} 48^{\prime} 05.9^{\prime \prime} \\
\text { W57 } 15^{\circ} 35.9^{\prime \prime}\end{array}$ & $6.39 \pm 0.07$ & $1.57 \pm 0.67$ & $72.23 \pm 0.85$ & $22.27 \pm 2.37$ & 15.00 \\
\hline L13 & Figueira & $\begin{array}{l}\mathrm{S} 17^{\circ} 48^{\prime} 32.5^{\prime \prime} \\
\text { W57 }\end{array}$ & $6.36 \pm 0.19$ & $1.55 \pm 0.05$ & $\begin{array}{c}55.23 \pm \\
25.59\end{array}$ & $26.10 \pm 0.72$ & $15 \pm 0.0$ \\
\hline L14 & Bigueirinho & $\begin{array}{l}\mathrm{S} 17^{\circ} 48^{\prime} 07.7^{\prime \prime} \\
\text { W57 } \\
\text { W } 34^{\prime} 05.5^{\prime \prime}\end{array}$ & $6.43 \pm 0.08$ & $1.51 \pm 0.10$ & $71.87 \pm 4.53$ & $25.83 \pm 0.38$ & $11.67 \pm 2.89$ \\
\hline L15 & Canafisto & $\begin{array}{l}\mathrm{S} 17^{\circ} 47^{\prime} 33.8^{\prime \prime} \\
\text { W57 } \\
3^{\circ} 18.9^{\prime \prime}\end{array}$ & $6.34 \pm 0.05$ & $1.57 \pm 0.06$ & $68.97 \pm 0.67$ & $25.77 \pm 0.32$ & $20 \pm 5.0$ \\
\hline
\end{tabular}

L1 to L15 = Lakes, D.O. = Dissolved oxygen, E.C. $=$ Electrical conductivity, W.T. $=$ Water temperature.
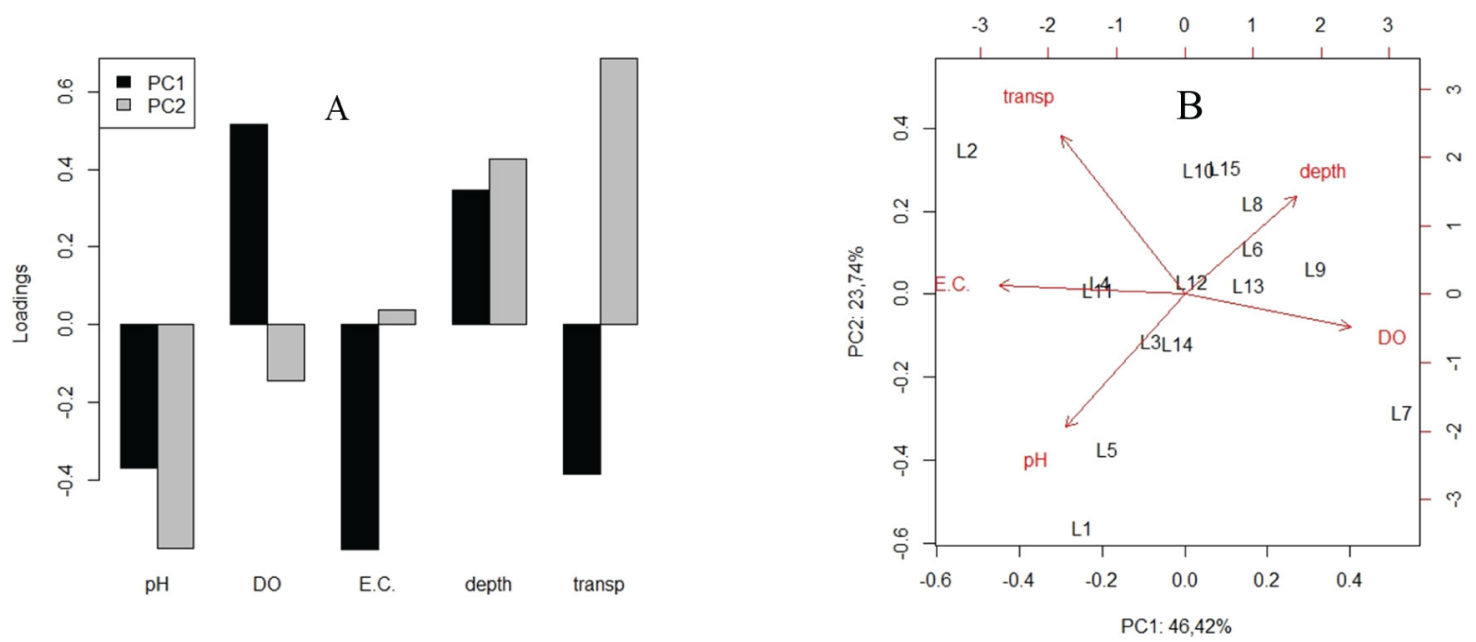

Figure 3. Result of the Principal Components Analysis (PCA) for the physiochemical variables showing the variable, its loadings (A) and the percentage of variance explained through the two first components (B) in the 15 marginal lakes along to the Paraguay River, MT sampled in September of 2005. (B) in the 15 marginal lakes along to the Paraguay River, MT sampled in September of 2005. 
Trichoptera in the lakes, both axes of the PCoA represented $99.99 \%$ of the data variation.

The relationship between Trichoptera community and the physicochemical variables were analyzed using Generalized Linear Models between the axes of PCoA, PCA and the abundance of L. fortunei $(\mathrm{p}<0.05)$. We did not find relationship in the model (i), which comprehends average abundance of Trichoptera (PCoA) in relation to the axes of PCA and the abundance of $L$. fortunei. The multivariate multiple regression demonstrated that the ordination of the Trichoptera community in model (ii), in the average abundance of the genera of Trichoptera (PCoA) in relation to the PCA axes and abundance of $L$. fortunei was significant, with the first PCA axes represented mainly by dissolved oxygen and conductivity (Pillai's Trace $=0.717$;
$\left.\mathrm{F}_{2,10}=11,444 ; \mathrm{p}=0.003\right)$. The multivariate multiple regression indicated that the community of Trichoptera was not significantly related with L. fortunei abundance (Pillai's Trace $=0.050$; $\left.\mathrm{F}_{2,10}=0.128 ; \mathrm{p}=0.970\right)$, neither with axes 2 of the PCA (Pillai's Trace $=0.185 ; \mathrm{F}_{2,10}=1.028 ; \mathrm{p}=0.396$ ).

In model (iii), in which we used the average abundance of Trichoptera (PCoA) in relation to the axes of the PCA, we found significant relationship with the PC1 (conductivity and dissolved oxygen) (Pillai's Trace $=0.505 ; \mathrm{F}_{2,11}=5,614 ; \mathrm{p}=0.020$ ) (Figure 4B). In the average abundance of the genera of Trichoptera (PCoA) in relation to the axes of the PCA, and excluding L. fortunei in the model (iv), the relationship with the first PCA axes was sharper (Pillai's Trace $=0.7154 ; \mathrm{F}_{2,11}=13,8289 ; \mathrm{p}=0.0009$ ) (Figure 4A).

Table 2. Taxonomic composition, abundance relative (\%) and Spearman correlation of genera average abundance, average abundance total of Trichoptera and of $L$. fortune $i$ with physicochemical variables in the 15 marginal lakes along the Paraguay River, MT.

\begin{tabular}{|c|c|c|c|c|c|}
\hline Taxa & $\%$ & $\mathrm{pH}$ & $\begin{array}{c}\text { DO } \\
\left(\mathrm{mg} \cdot \mathrm{L}^{-1}\right)\end{array}$ & $\begin{array}{c}\text { E.C. } \\
\left(\mu S . \mathrm{cm}^{-1}\right)\end{array}$ & $\begin{array}{l}\text { Depth } \\
\text { (cm) }\end{array}$ \\
\hline Flintiella sp. Angrisano, 1995 & 0.02 & & & & \\
\hline Hydroptila sp. Dalman, 1819 & 0.19 & & & & \\
\hline Neotrichia sp1. Morton, 1905 & 0.42 & & & & \\
\hline Neotrichia sp2.Morton, 1905 & 57.55 & & $-0.707^{* *}$ & & $-0.582 *$ \\
\hline Oxyethira sp. Eaton, 1873 & 0.53 & $-0.569 n s$ & & $0.676 n s$ & $-0.542 n s$ \\
\hline Hydroptilinae & 0.02 & & & & \\
\hline Cyrnellus sp. Banks, 1913 & 1.93 & & & & $-0.503 n s$ \\
\hline Polycentropus sp. Ulmer, 1905 & 17.66 & & $-0.521 *$ & & \\
\hline Macronemasp. Pictet, 1836 & 5.48 & $0.512 * *$ & $-0.531 \mathrm{~ns}$ & $0.611 \mathrm{~ns}$ & \\
\hline Smicrideasp. McLachlan, 1871 & 0.02 & & & & \\
\hline Oecetis sp. McLachlan & 12.96 & & $-0.639 *$ & & $-0.643^{*}$ \\
\hline Nectopsyche sp.Muller & 3.19 & & $-0.629 n s$ & & \\
\hline Leptoceridae & 0.02 & & & & \\
\hline Average abundance Trichoptera & 100 & & $-0.746 * *$ & & $-0.618^{*}$ \\
\hline
\end{tabular}

${ }^{*} \mathrm{p}<0.05 .{ }^{* *} \mathrm{p}<0.01 . \mathrm{ns}=$ non significant.

$r, M$
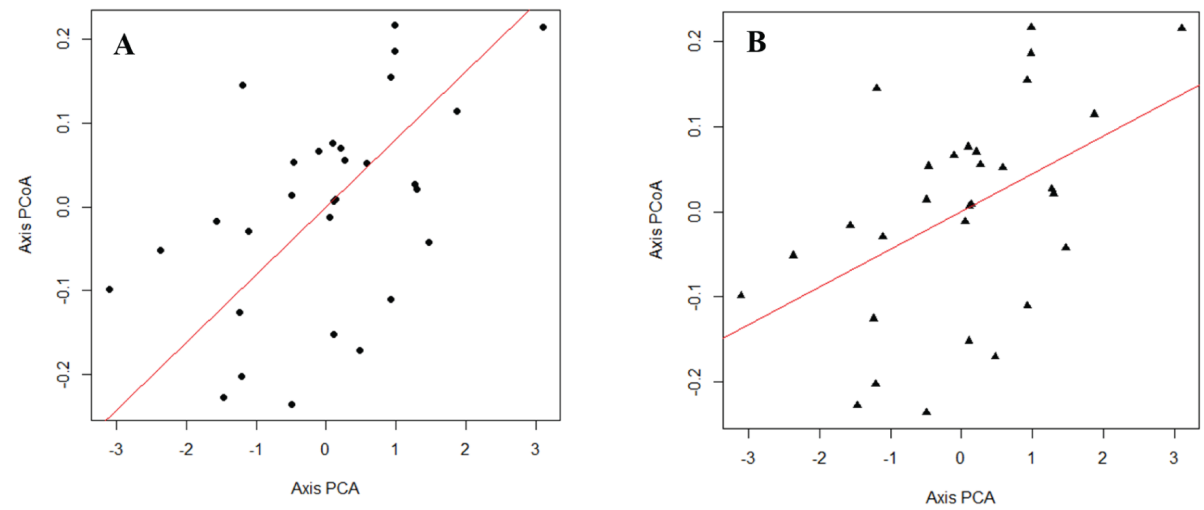

Figure 4. Relationship of the axes PCoA (A) average abundance of Trichoptera genera; (B) average abundance of Trichoptera) associated to E. crassipes with PCA axis (physiochemical variables) in the 15 marginal lakes along the Paraguay River, MT, sampled in September 2005. 


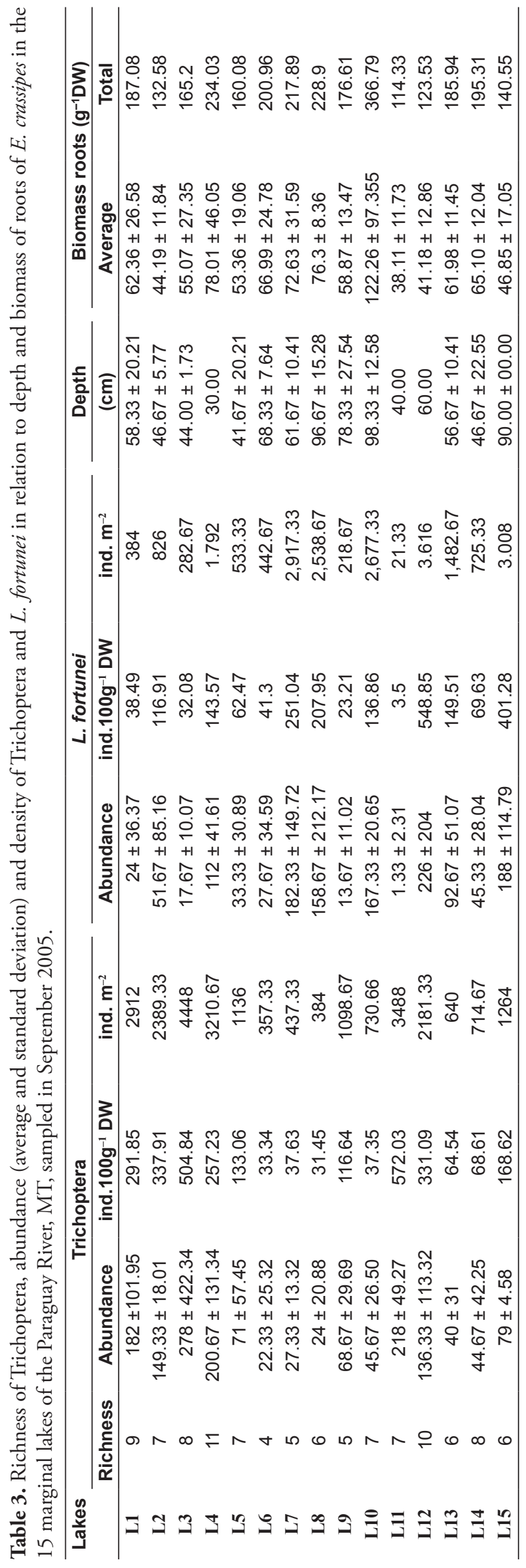


The multivariate multiple regressions corroborated with the Spearman correlation, because a negative correlation of dissolved oxygen and depth with the average abundance of Trichoptera (Figure 5A1 and A2) and the average abundance of the Neotrichias p2. (Figure 5B1 and B2) and Oecetis
(Figure 5C1 and C2) occurred. The conductivity, in spite of correlating negatively with the PC1, did not demonstrate a direct influence on the genera of Trichoptera, but affected indirectly the average abundance of Macronema sp., by means of correlation with the $\mathrm{pH}$ (Figure 5D3).
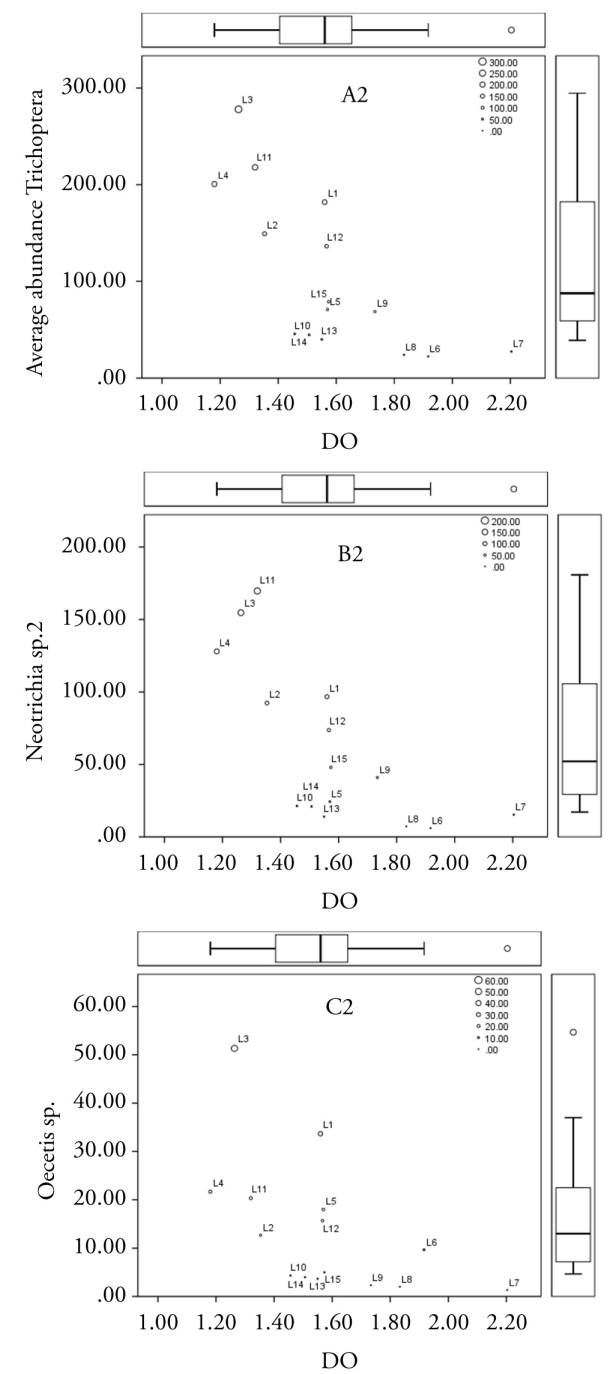

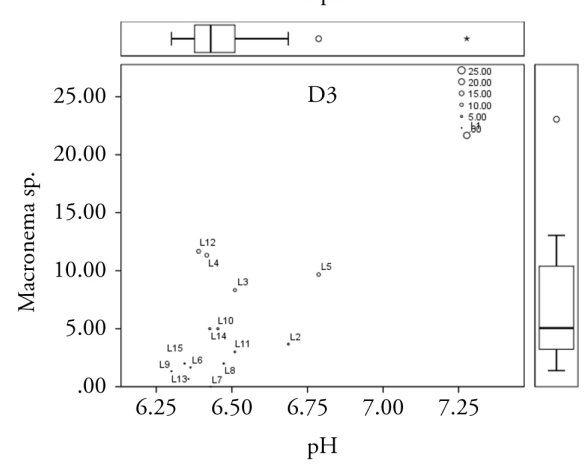

Figure 5. Distribution of the average abundance of Trichoptera (A) and average abundance of genera Neotrichia (B), Oecetis (C) and Macronema (D) associated to E. crassipes in the gradient of depth (1), dissolved oxygen (2) and $\mathrm{pH}$ (3) of the in the 15 marginal lakes along the Paraguay River, MT, sampled in September 2005. (1), dissolved oxygen (2) and $\mathrm{pH}$ (3) of the in the 15 marginal lakes along the Paraguay River, MT, sampled in September 2005. 
The depth gradient and the concentration of dissolved oxygen in the lakes waters ordered the composition and abundance of genera affecting the Trichoptera fauna in the dry season (Table 2; Figure 5A1 and A2). Of the 13 taxa collected, 11 occurred at lower oxygen concentrations, being that Neotrichia sp2., Polycentropus, Cyrnellus, Macronema, Oecetis and Nectopsyche occurred in the whole gradient of the concentration and depth (Table 2), being the more abundant genera (Neotrichia sp2. and Oecetis sp.) negatively related to both variables (Figure $5 \mathrm{~B}$ and $5 \mathrm{C}$ ) and the others with one of them (Table 2). Smicridea sp., Leptoceridae and Flintiella sp. were only found within this gradient of DO (1.1 to $\left.1.5 \mathrm{mg} . \mathrm{1}^{-1}\right)$ and depth $(25$ to $50 \mathrm{~cm})$. Hydroptilinae e Hydroptila occurred only in intermediary DO concentration (1.5 to $1.9 \mathrm{mg} .1^{-1}$ ) and depth above $50 \mathrm{~cm}$. The occurrence of species in the extreme of the gradient concentration (1.9-2.3 mg. $\left.1^{-1}\right)$ coincided with those that occur in the entire gradient (Table 2).

\section{Discussion}

The abundance of exotic golden mussels does not affect the structure of caddisfly community associated to the roots of E. crassipes in the lakes of Paraguay River, but we found significant relationship between caddisfly and the environment. The absence of effects in the density of Trichoptera by golden mussels can be expressed by the inherent characteristics of the natural habitat and species (Strayer et al., 2011; Marçal \& Callil, 2012; Uhde et al., 2012; Boltovskoy, 2015). Trichoptera presents varying degrees of tolerance to natural and anthropogenic disturbances, making them excellent indicators of ecosystem health (Myers et al., 2011), but the taxa sampled are naturally favored in shallow lakes. Considering the environmental data, our results demonstrate that the community of Trichoptera living in association with $E$. crassipes has a successful adaptability to environmental conditions in the water of the Pantanal floodplain. Dissolved oxygen is a structuring factor for this insect community, determining the abundance and occurrence of the genera in the lakes. It is associated with an unknown factor in this study related to the quality of microhabitat for the larvae of Trichoptera. The most abundant genera, such as Neotrichia sp2. and Oecetis sp. were found throughout the dissolved oxygen gradient, but they had their abundance decreased with the increase of this gradient. The genera with slighter occurrence, and therefore less representative in abundance, were restricted to a range of gradient of DO and depth, such as Smicridea sp., Leptoceridae and Flintiella, which occurred only in the lowest oxygen concentrations.

The most marginal shallow lakes of the Pantanal (Wantzen et al., 2005; Oliveira et al., 2006) are characterized by low values of oxygen in the water, and this is strongly influenced by the depth, as in deep lakes little oxygen is consumed faster (Cremona et al., 2008). In the Paraguay River, during the dry season, the hydrological connectivity is reduced and the lakes become more susceptible to the influence of local processes such as rain, wind and decomposition of macrophytes (Marchese et al., 2005; Thomaz et al., 2007), but they do not present a clear pattern of deoxygenating due to the flow speed variation in different places (Poi de Neiff, 2003). All of these factors may indirectly influence the micro distribution of invertebrate, including Trichoptera larvae in lakes of seasonally floodplains. Thus, we observed a depth gradient pattern downstream-upstream of the lakes for Trichoptera and L. fortunei. The lakes L1 until to L5 (downstream) were the shallowest with highest density and richness of Trichoptera and less of $L$. fortunei that prefer deeper lakes, occurring at higher density at upstream lakes. Apparently, the depth and the oxygen dissolved in the water interfere in different ways in caddis and mussels density in macrophytes.

We observed that in marginal regions of shallower lakes covered by aquatic plants have lower concentrations of oxygen in the water. The oxygen deficit is usually a stress factor for aquatic invertebrates, causing a decline in total abundance and an increase in the number of species adapted for survival under hypoxic conditions (Irmler, 1975; Poi de Neiff \& Carignan, 1997). However, the depth and oxygen are covariant factors (Cremona et al., 2008), that contribute to the advancement of seasonal succession process in water bodies of the Pantanal. Thus, the succession process and progress of senescence of aquatic plants is dependent on the quantity and quality of water in the lakes, as observed in lakes connected to Paranapanema River (Stripari \& Henry, 2002; Silva \& Henry, 2013). During the dry season, dissolved oxygen in water presented negative correlations between decomposition rates of macrophytes (Stripari \& Henry, 2002), which explains higher density of Trichoptera in lakes with less depth and OD. Nevertheless, aquatic plants that form floating mats, such as water hyacinth (E. crassipes), can 
decrease macroinvertebrate abundance by blocking light transmission and decreasing photosynthesis by phytoplankton and others plants, leading to anoxic condition in shore lakes (Masifwa et al., 2001).

We believe that low concentrations of oxygen in the marginal regions of the lakes leads to both decomposition and low photosynthesis, causing periodic fluctuations in abundances of adapted communities, such as Trichoptera. The presence of regular hydrological phases interferes in the abundances and in the life-cycle of the populations, so that the life-history adaptations typically involve the synchronization of life-cycle events, such as reproduction and growth, in relation to the long-term average dynamics of the flow regime (Lytle \& Poff, 2004).This implies, higher productivity with extraordinary concentration of individuals, greater resilience in process cyclic succession, and higher functional redundancy (Walker, 1992).

The depth gradient of marginal lakes with low water level causing oxygen depletion in dry season affects the quality of the habitat (E. crassipes), and consequently the abundance of Trichoptera and L. fortunei. Similar condition of greater density of Trichoptera, as Oecetis inconspicua (Walker, 1852) (Leptoceridae), in vegetated lakes with shallow marginal region (Strayer \& Smith, 2001), is explained by the high primary production of periphyton. The invertebrate density presents an inverse relationship with the remaining biomass of macrophyte during the decomposition (Bruquetas de Zozaya \& Neiff, 1991), because during decomposition, bacteria and fungus and later of periphytic algae produced an increase in nitrogen and protein, and the detritus became attractive as food source of the invertebrates (Masifwa et al., 2001; Weatherhead \& James, 2001; Stripari \& Henry, 2002). Thereby, the stage of succession of E. crassipes apparently interferes in the richness and abundance of genera and trophic structure of the community, that was characterized by occurrence of micro-caddisfly, favored E. crassipes by the food provided in their roots (Stripari \& Henry, 2002; Mormul et al., 2006; Poi de Neiff \& Neiff, 2006; Silva \& Henry, 2013).

The effect of an invasive species is more assertive in species directly connected via a chain of consumption than those that have indirect relations but, our results demonstrate greater abundance of collectors; detritus eaters and periphyton scrapers as Neotrichia and moderate amount of filterers, like Cyrnellus, Polycentropus and Macronema sp.
In the floodplain, river and lake areas, Neotrichia comprise the fauna of collectors in the first stages of decomposition of aquatic macrophytes (Poi de Neiff \& Bruquetas de Zozaya, 1991). Thus, it is clear that the succession in these plants for the invertebrate species has a relationship with time of decomposition expressed by the loss of biomass, and probably the individuals of this taxon are later colonizer in terms of accumulation of debris on the roots. The loss of planktonic food via mussel's filtration activity is compensated by increased production of aquatic macrophytes, periphyton and detritus amortizing any effect on food webs of the littoral zone (Strayer et al., 2011). Thus, the influence on filter feeders as Polycentropodidae and Hydropsychidae would not be observed depending on the amount of resources available in macrophytes.

The consequences of the presence of invasive species to the invertebrate fauna can be variable, depending of the community's characteristics, physicochemical conditions, structure of habitats, and the density potentiality of invasive species (Stachowicz \& Tilman, 2005; Bruno et al., 2005). In general, in shallower lakes the density of $L$. fortunei was lower, and despite not being the hypothesis testing, the density of the species showed a relationship with the gradient downstream-upstream of depth of the lakes, with a trend of higher mussel density in deep lakes (upstream) and less density at downstream shallow lakes, connected to oxygen suppression at shallower depths. The reduction in population size of $L$. fortunei in Pantanal was cited by Oliveira et al. (2010a), resulting from the oxygen depletion events caused by increasing the decomposition of organic matter, during the rising water phase; a phenomenon locally known as "dequada". The seasonal depletion of oxygen in the water in the Paraguay River and other rivers of the Pantanal, during some months of the year, combined with other factors (low calcium, low $\mathrm{pH}$, low chlorophyll a concentrations, high suspended solids and water velocity) explain the low density of L. fortunei in some areas of the Pantanal (Oliveira et al., 2010b, 2011). However, the dissolved oxygen has been found as a factor that regulates the reproductive activity and survival of the golden mussel, impeding its uncontrolled proliferation (Oliveira et al., 2010b, 2011; Eilers et al., 2011; Bonel et al., 2013), limiting the abundance increase, but not interfering in the establishment of the species (Oliveira et al., 2010b). Perepelizin \& Boltovskoy (2015) consider that oxygen deprivation may be a viable alternative for the control of mussel fouling in 
industrial installations, because they observed total mortality at dissolved oxygen levels $<0.16 \mathrm{mg} / \mathrm{Lafter}$ 10-12 days (at $27^{\circ} \mathrm{C}$ ), in addition to higher mortality of smaller mussels $(7 \mathrm{~mm})$ when oxygen deprivation occurs in lower temperature (at $20^{\circ} \mathrm{C}$ ). The data presented in our study, show that during the dry season, the lowest percentage of oxygen in shallow lakes, also acts as controller for population L. fortunei, associated with other covariates factors, as water temperature, typically high in the Paraguay River (occasional cold fronts 19.4 to $26.1^{\circ} \mathrm{C}$ ). Thus, population growth of $L$. fortunei no Pantanal is associated with the hydroperiod, which makes habitat conditions and environmental variables unfavorable at different times of seasonal cycle (dry season; rising season see Oliveira et al., 2010a, b, 2011).

The gregarious habit and the scarcity of stable substrates on the bottom of the rivers and lakes also contribute to the control of the L. fortunei population. The instability of E. crassipes as a substrate and its brief life cycle makes it a refuge, a place with food resources and suitable setting for epibenthic species with seasonal life cycles. As this species of Mytilidae have indirect development, while stage veliger is easily dispersed by water column and after become pediveliger and post-larvae, it needs to fix to complete their development, thereby increasing the filtration, and thus, reach sexual maturity (Santos et al., 2005). Among other strategies the golden mussels assume, the most viable in the Pantanal, is the association of young roots epiphytic macrophytes, initially attracted by periphyton, source of oxygen and food. Because it is a sedimentation basin (Junk et al., 2006), the availability of hard substrates to the successfully installation of the golden mussel is limited in the Pantanal. Thus, low densities of L. fortunei in the Pantanal, when compared with Argentina and southern Brazil showing amounts of about 145,000 ind.m ${ }^{-2}$ (Boltovskoy et al., 2006; Mansur et al., 2003), also show the limitations of the environment - 'ecosystem resistance' for the development of the population of the invader.

Trichoptera larvae also have more gregarious habits (Wiggins et al., 1980) but, these immature insects usually have morphological and physiological adaptations (Holomuzki \& Biggs, 2000), which are determinants for the increased tolerance or escape ability in environments susceptible to drought (Wiggins et al., 1980). The immature Leptoceridae and Hydroptilidae family have morphed-ecological adaptations that increase their respiratory efficiency and enable them to survive in lentic environments with low concentrations of oxygen (Wiggins, 2000). In this context, the negative correlation of the most abundant genera (Neotrichia sp2, Oecetis sp.) with dissolved oxygen and depth may be related to the fact that the larvae of these genera of caddisflies, as well as some immature Lepidoptera and Diptera-Chironomidae, use body ventilation to pump water through their tubes (Merritt \& Cummins, 1996). Whence, most caddis builders' tubes are late colonizers in the succession process when compared to other invertebrates (Albertson et al., 2011).

The caddisfly associated with macrophytes could be negatively affected by dense populations of golden mussel settled in the Pantanal floodplains. In this study, however, the populational density this exotic mollusk was low. The magnitude of the impacts of the $L$. fortune $i$ in the biota is related to the population size of invasive species and the invaded system susceptibility (Hicks, 2004). L. fortunei like D. polimorpha (Karatayev et al., 2010), has competitive advantages such as high reproductive capacity (Darrigran et al., 2009; Callil et al., 2012) and dispersion strategy (Oliveira et al., 2011) classifying it as a successful invasive species. However, after its spread in the habitat, the harmful effects to the environment are dependent on the level of stability and resilience of the ecosystem where the species was introduced (Stachowicz \& Tilman, 2005; Strayer et al., 2011), and only longterm studies will show which groups will be affected by L. fortunei in the Pantanal aquatic habitats.

Caddisfly associated with water hyacinth roots showed adaptation to the environment characterized by hypoxic conditions in the dry season, while L. fortunei was limited by the depth and oxygen reduction, with lower densities in ponds with these characteristics. So, dissolved oxygen is a structuring factor for this insect community, determining the abundance and occurrence of genera in the lakes. Opportunistic species as Neotrichia sp. may be favored by an increase of detritus and recourses of animal and plant origin (periphyton, testate amoebas, bio-deposition) accumulated in the roots. It is important to distinguish the effects of grouping valves phytophilous fauna those observed for the benthic fauna. The macrofouling serves as an additional substrate available to a variety of organisms and its tridimensional structure increases the complexity of the habitat (Ricciardi et al., 1997; Boltovskoy et al., 2006, 2009; Sylvester et al., $2007 \mathrm{~b})$. The input of organic material from filtration and bio-deposition increase the density 
and biomass of trophic groups (Burlakova et al., 2012) and the empty shells accumulate to form reefs that provide additional hard structures that act as refuges (Sardiña et al., 2008). So, L. fortunei as $D$. polymorpha act as a very effective ecosystem engineer, altering both ecosystem structure and function (Sylvester et al. 2007a; Darrigran \& Damborenea, 2011). Macrofouling of mussel shells may not signify much to the structural complexity in macrophytes, but this needs to be properly tested. A study on the differences between substrates and colonized communities (epibenthic fauna associated with macrophytes and benthic fauna) by $L$. fortune $i$ bring new elements of effectiveness of this species as ecosystem engineer.

We believe that the action of $L$. fortunei in invertebrate communities depends on the behavior and the niches occupied by components of the community - 'biotic resistance' as well as the limitations of the environment - 'ecosystem resistance' for the development of the population of the invader. We know that the equilibrium of a natural system depends of the structure of the environment, which reflects how healthy it is, the functioning, determined not only resistance but also the range of resilience. The action of an invasive species with a high power of interference in these attributes, integrity and stability, should receive continuous attention. Whence, the maintenance of the natural flooding cycle in the Pantanal is essential for the renewal of macrophytes and the fauna that thrive in this community. We also highlight the need to carry out continuous monitoring of the invasion of $L$. fortunei on the Upper Paraguay basin, as well as studies with sampling designs to identify the specific effects of this invader on different trophic niches.

\section{Acknowledgements}

To Coordenação de Aperfeiçoamento de Pessoal de Nível Superior (CAPES), Fundação de Amparo à Pesquisa do Estado de Mato Grosso (FAPEMAT; process number 4.2.2.82/02-2004-E) and Programa de Pós Graduação em Ecologia e Conservação da Biodiversidade (PPGECB) for the financial support. Special thanks to Leandro G. Oliveira (UFG) and Ana Maria Pés (INPA) for the confirmation of the genera identified. Thanks also to the NEPA Núcleo de Estudos Ecológicos do Pantanal and to the colleagues of the Aquatic Ecology Lab for the field and lab assistance.

\section{References}

ALBERTSON, L.K., CARDINALE, B.J., ZEUG, S.C., HARRISON, L.R., LENIHAN, H.S. and WYDZGA, M.A. Impacts of channel reconstruction on invertebrate assemblages in a restored river. Restoration Ecology, 2011, 19(5), 627-638. http:// dx.doi.org/10.1111/j.1526-100X.2010.00672.x.

BISPO, P.C., OLIVEIRA, L.G., BINI, L.M. and SOUSA, K.G. Ephemeroptera, Plecoptera and Trichoptera assemblages from riffles in mountain streams of Central Brazil: environmental factors influencing the distribution and abundance. Revista Brasileira de Zoologia, 2006, 66(2), 611-622. PMid:16906293.

BOLTOVSKOY, D. Limnoperna fortunei, the ecology, distribution and control of a swiftly spreading invasive fouling mussel. Cham: Springer, 2015, 476 p. Invading Nature - Springer Series in Invasion Ecology, vol. 10.

BOLTOVSKOY, D., CORREA, N., CATALDO, D. and SYLVESTER, F. Dispersion and ecological impact of the invasive freshwater bivalve Limnoperna fortunei in the Rio de la Plata watershed and beyond. Biological Invasions, 2006, 8(4), 947-963. http:// dx.doi.org/10.1007/s10530-005-5107-z.

BOLTOVSKOY, D., KARATAYEV, A., BURLAKOVA, L., CATALDO, D., KARATAYEV, V., SYLVESTER, F. and MARINEELARENA, A. Significant ecosystemwide effects of the swiftly spreading invasive freshwater bivalve Limnoperna fortunei. Hydrobiologia, 2009, 636(1), 271-284. http://dx.doi.org/10.1007/ s10750-009-9956-9.

BONEL, N., SOLARI, L.C. and LORDA, J. Differences in density, shell allometry, and growth between two populations of Limnoperna fortunei (Mytilidae) from the Río de la Plata basin, Argentina. Malacologia, 2013, 56(1-2), 43-58.

BRUGNOLI, E., CLEMENTE, J., BOCCARDI, L., BORTHAGARAY, A. and SCARABINO, F. Golden mussel Limnoperna fortunei (Bivalvia: Mytilidae) distribution in the main hydrographical basins of Uruguay update and predictions. Anais da Academia Brasileira de Ciências, 2005, 77(2), 235-244. http:// dx.doi.org/10.1590/S0001-37652005000200004. PMid: 15895160.

BRUNO, J.F., FRIDLEY, J.D., BROMBERG, K. and BERTNESS, M.D. Insights into biotic interactions from studies of species invasions. In D.F. SAX, J.J. STACHOWICZ and S.D. GAINES, eds. Species invasions: insights into ecology, evolution and biogeography. Sunderland: Sinauer Associates, Inc. Publishers, 2005, pp. 13-40.

BRUQUETAS DE ZOZAYA, I.Y. and NEIFF, J.J. 1991. Decomposition and colonization by invertebrates of Typha latifolia L. litter in chaco cattai swamp (Argentina). Aquatic Botany, 40(2), 185-193.

BURLAKOVA, L.E., KARATAYEV, A.Y. and KARATAYEV, V.A. Invasive mussels induce community changes by increasing habitat complexity. Hydrobiologia, 2012, 685(1), 121-134. http://dx.doi. org/10.1007/s10750-011-0791-4. 
CALLIL, C.T., TEIXEIRA, A.L., PINILUS, A.C. and SOARES, V. A gametogênese em Limnoperna fortunei (Dunker, 1857). In M.C.D. MANSUR, C.P. SANTOS, D. PEREIRA, I.C.P. PAZ, M.L.L. ZURITA, M.T.R. RODRIGUEZ, M.V. NEHRKE and P.E.A. BERGONCI, orgs. Guia prático: moluscos límnicos Invasores do Brasil: biologia, prevenção e controle. Porto Alegre: Redes Editora, 2012, pp. 111-118.

CREMONA, F., PLANAS, D. and LUCOTTE, M. Biomass and composition of macroinvertebrate communities associated with different types of macrophytes architectures and habitats in a large fluvial lake. Fundamental and Applied Limnology. Archiv für Hydrobiologie, 2008, 171(2), 119-130. http://dx.doi.org/10.1127/1863-9135/2008/01710119.

DARRIGRAN, G. and DAMBORENEA, C. Características da espécie. In G. DARRIGRAN and C. DAMBORENEA, eds. Introdução a biologia das invasöes: o mexilhão dourado na América do Sul: biologia, dispersão, impacto, prevenção e controle. São Carlos: Editora Cubo, 2009, pp. 43-58.

DARRIGRAN, G. and DAMBORENEA, C. Ecosystem Engineering Impact of Limnoperna fortunei in South America. Zoological Science, 2011, 28(1), 1-7. http:// dx.doi.org/10.2108/zsj.28.1. PMid:21186940.

DARRIGRAN, G., BOEGER, W., DAMBORENEA, C. and MARONAAS, M. Evaluation of sampling and analysis techniques for early detection of Limnoperna fortunei (Mytilidae) in limit areas of its distribution. Brazilian Journal of Biology $=$ Revista Brasileira de Biologia, 2009, 69(3), 979-980. http:// dx.doi.org/10.1590/S1519-69842009000400029. PMid:19802461.

DARRIGRAN, G., MARTIN, S.M., GULLO, B. and ARMENDARIZ, L. Macroinvertebrate associated to Limnoperna fortunei (Dunker,1857) (Bivalvia, Mytilidae). Río de La Plata, Argentina. Hydrobiologia, 1998, 367(1/3), 223-230. http:// dx.doi.org/10.1023/A:1003244603854.

DOMÍNGUEZ, E. and FERNÁNDEZ, H.R. Macroinvertebrados bentónicos sudamericanos: sistemática y biología.Tucumán: Fundación Miguel Lillo, 2009, 253 p.

EILERS, V., OLIVEIRA, M.D. and ROCHE, K.F. Density and body size of the larval stages of the invasive golden mussel (Limnoperna fortunei) in two neotropical rivers. Acta Limnologica Brasiliensia, 2011, 23(3), 282-292. http://dx.doi.org/10.1590/ S2179-975X2012005000006.

ESPINOLA, L.A. and JÚLIO JUNIOR, H.F. Especies invasoras: conceptos, modelos y atributos. Interciencia, 2007, 32(9), 580-585.

GOTELli, N.J. and ELLISON, A.M. Principios de estatística em ecologia. Porto Alegre: Artmed, 2010, $683 \mathrm{p}$.
HICKS, G. Turning the tide: is aquatic bioinvaders research heading in the right direction? Aquatic Invaders, 2004, 15(1), 9-20.

HOLOMUZKI, J.R. and BIGGS, B.J.F. Taxon-specific responses to high-flow disturbance in streams: implications for population persistence. Journal of the North American Benthological Society, 2000, 19(4), 670-679. http://dx.doi.org/10.2307/1468125.

IRMLER, U. Ecological studies of the aquatic soil invertebrates in three inundations. Amazoniana, 1975, 3(3), 337-409.

JUNK, W.J., BROWN, M., CAMPBELL, I.C., FINLAYSON, M., GOPAL, B., RAMBERG, L. and WARNER, B.G. The comparative biodiversity of seven globally important wetlands: a synthesis. Aquatic Sciences, 2006, 68(3), 400-414. http://dx.doi. org/10.1007/s00027-006-0856-z.

KARATAYEV, A., BURLAKOVA, E.L., KARATAYEV, V.A. and BOLTOVSKOY, D. Limnoperna fortunei $\mathrm{x}$ Dreissena polymorpha: Population density and benthic community impacts of two invasive freshwater bivalves. Journal of Shellfish Research, 2010, 29(4), 975-985. http://dx.doi.org/10.2983/035.029.0432.

LEGENDRE, P. and LEGENDRE, L. Numerical ecology. Amsterdam: Elsevier Science BV, 1998, 853 p.

LYTLE, D.A. and POFF, N.L. Adaptation to natural flow regimes. Trends in Ecology \& Evolution, 2004, 19(2), 94-100. http://dx.doi.org/10.1016/j. tree.2003.10.002. PMid:16701235.

MANSUR, M.C.D., SANTOS, C.P., DARRIGRAN, G., HEYDRICH, I., CALLIL, C.T. and CARDOSO, F.R. Primeiros dados quali-quantitativos do Mexilhão dourado Limnoperna fortunei (Dunker, 1857), no lago Guaíba, Bacia da Lagoa dos Patos, Rio Grande do Sul, Brasil e alguns aspectos de sua invasão no novo ambiente. Revista Brasileira de Zoologia, 2003, 20(1), 75-84. http://dx.doi.org/10.1590/S010181752003000100009 .

MARÇAL, S.F. and CALLIL, C.T. Estrutura da comunidade de invertebrados associados à Eichhornia crassipes Mart. (Solms-Laubach) após a introdução de Limnoperna fortunei (Dunker, 1857) (Bivalvia, Mytilidae) no Alto Rio Paraguai, MT, Brasil. Acta Limnologica Brasiliensia, 2008, 20(4), 117-130.

MARÇAL, S.F. and CALLIL, C.T. Limnoperna fortunei em macrófitas na Bacia do rio Paraguai, Mato Grosso. In M.C.D. MANSUR, C.P. SANTOS, D. PEREIRA, I.C.P. PAZ, M.L.L. ZURITA, M.T.R. RODRIGUEZ, M.V. NEHRKE and P.E.A. BERGONCI, orgs. Guia prático: moluscos limnicos invasores do Brasil: biologia, prevenção e controle. Porto Alegre: Redes Editora, 2012, pp. 201-206.

MARCHESE, M.R., WANTZEN, K.M. and DRAGO, E. Benthic invertebrate assemblages and species diversity patterns of the Upper Paraguay River. River Research and Applications, 2005, 21(5), 485-499. http://dx.doi.org/10.1002/rra.814. 
MASIFWA, W.F., TWONGO, T. and DENNY, P. The impact of water hyacinth, Eichhornia crassipes (Mart) Solms on the abundance and diversity of macroinvertebrates along the shores of northern Lake Victoria, Uganda. Hydrobiologia, 2001, 452(1-3), 7988. http://dx.doi.org/10.1023/A:1011923926911.

MERRITT, R.W. and CUMMINS, K.W. An introduction to the aquatic insects of North America. 2nd ed. Iowa: Kendall Hunt Publishing, 1996, 862 p.

MORMUL, R.P., VIERA, L.A., PRESSINATTI JUNIOR, S., MONKOLSKI, A. and SANTOS, A.M. Sucessão de invertebrados durante o processo de decomposição de duas plantas aquáticas (Eichhornia azurea e Polygonum ferrugineum). Biological Sciences, Acta Scientiarum, 2006, 28(2), 109-115. http:// dx.doi.org/10.4025/actascibiolsci.v28i2.1017.

MYERS, L.W., KONDRATIEFF, B.C. and MILUC, T.B. The mayflies (Ephemeroptera), stoneflies (Plecoptera), and caddisflies (Trichoptera) of the Adirondack Park (New York). Transactions of the American Entomological Society, 2011, 137(1-2), 63-140. http://dx.doi.org/10.3157/061.137.0118.

OHTAKA, A., NARITA, T., KAMIYA, T., KATAKURA, H., ARAKI, Y., IM, S., CHHAY, R. and TSUKAWAKI, S. Composition of aquatic invertebrates associated with macrophytes in Lake Tonle Sap, Cambodia. Limnology, 2011, 12(2), 137144. http://dx.doi.org/10.1007/s10201-010-0330-4.

OKSANEN, J., BLANCHET, F.G., KINDT, R., LEGENDRE, P., MINCHIN, P.R., O'HARA, R.B., SIMPSON, G.L., SOLYMOS, P., STEVENS, M.H.H. and WAGNER, H. Vegan: community ecology package. R package version 2.0-8 [software]. Vienna: The R Project for Statistical Computing, 2013.

OLIVEIRA, M.D., CALHEIROS, D.F., JACOBI, C.M. and HAMILTON, S.K. Abiotic factors controlling the establishment and abundance of the invasive golden mussel Limnoperna fortunei. Biological Invasions, 2011, 13(3), 717-729. http://dx.doi. org/10.1007/s10530-010-9862-0.

OLIVEIRA, M.D., HAMILTON, S. and JACOBI, C. Forecasting the expansion of the invasive golden mussel Limnoperna fortunei in Brazilian and North American rivers based on its occurrence in the Paraguay River and Pantanal wetland of Brazil. Aquatic Invasions, 2010b, 5(1), 59-73. http://dx.doi. org/10.3391/ai.2010.5.1.8.

OLIVEIRA, M.D., HAMILTON, S.K., CALHEIROS, D.F. and JACOBI, C.M. Oxygen depletion events control the invasive golden mussel (Limnoperna fortunei) in a tropical floodplains. Wetlands, 2010a, 30(4), 705-716. http://dx.doi.org/10.1007/s13157010-0081-3.

OLIVEIRA, M.D., TAKEDA, A.M., BARROS, L.F. and BARBOSA, S.D. Invasion by Limnoperna fortunei (Dunker, 1857) (Bivalvia, Mytilidae) of the Pantanal wetland, Brazil. Biological Invasions, 2006, 8(1), 97104. http://dx.doi.org/10.1007/s10530-005-0331-0.
PEREPELIZIN, P.V. and BOLTOVSKOY, D. Control of Limnoperna fortunei fouling by oxygen deprivation. In D. BOLTOVSKOY, ed. Limnoperna fortunei, the ecology, distribution and control of a swiftly spreading invasive fouling mussel. Cham: Springer International Publishing, 2015, pp. 451-454. Invading Nature. Springer Series in Invasion Ecology. http://dx.doi. org/10.1007/978-3-319-13494-9.

PESCADOR, M.L., RASMUSSEN, A.K. and HARRIS, S.C. 1995. Identification manual for the caddisfly (Trichoptera) larvae of Florida. Thalahassee: Departament of Environmental Protection, Division of Water Facilites, $186 \mathrm{p}$.

POI DE NEIFF, A. and BRUQUETAS DE ZOZAYA, I.Y. Colonización por invertebrados de macrófitos emergentes durante su decomposición em el río Paraná. Hydrobiologia Tropical, 1991, 24(3), 209-216.

POI DE NEIFF, A. and CARIGNAN, R. Macroinvertebrates on Eichhornia crassipes roots in two lakes of the Paraná River floodplain. Hydrobiologia, 1997, 345(2/3), 185-196. http:// dx.doi.org/10.1023/A:1002949528887.

POI DE NEIFF, A. and NEIFF, J.J. Riqueza de especies y similaridad entre invertebrados que viven en macrófitas de la planicie de inundación del río Paraná. Interciencia, 2006, 31(3), 220-225.

POI DE NEIFF, A. Macroinvertebrates living on Eichhornia azurea Kunth in the Paraguay River. Acta Limnologica Brasiliensia, 2003, 15(1), 55-63.

POTT, V.J., POTT, A., LIMA, L.C.P., MOREIRA, S.N. and OLIVEIRA, A.K. Aquatic macrophyte diversity of the Pantanal wetland and upper basin. Brazilian Journal of Biology $=$ Revista Brasileira de Biologia, 2011, 71, 255-263. Supplement 1. PMid:21537598.

R DEVELOPMENT CORE TEAM. $R$ : A language and environment for statistical computing [software]. Vienna: R Foundation for Statistical Computing, 2013. [viewed 02 Dec. 2015]. Available from: http:// www.R-project.org/

RICCIARDI, A., WHORISKEY, F.G. and RASMUSSEN, J.B. The role of the zebra mussel (Dreissena polymorpha) in structuring macroinvertebrate communities on hard substrata. Canadian Journal of Fisheries and Aquatic Sciences, 1997, 54(11), 2596-2608. http://dx.doi. org/10.1139/f97-174.

ROCHA-RAMÍREZ, A.R., ROCHA-ROJAS, A.R., CHAVES-LÓPEZ, R.C. and ALCOCER, J. Invertebrate assemblages associated with root masses of Eichhornia crassipes (Mart.) Solms-Laubach 1883 in the Alvarado Lagoonal System, Veracruz, Mexico. Aquatic Ecology, 2007, 41(2), 319-333. http://dx.doi. org/10.1007/s10452-006-9054-2.

SANTOS, C.P., WURDIG, N.I. and MANSUR, M.C.D. Fases Larvais do Mexilhão Dourado Limnoperna fortunei (dunker, 1857) (Mollusca Bivalvia Mytilidae) na Bacia do Guaiba, Rio Grande do Sul Brasil. Revista Brasileira de Zoologia, 2005, 
22(3), 702-708. http://dx.doi.org/10.1590/S010181752005000300029 .

SARDIÑA, P., CATALDO, D. and BOLTOVSKOY, D. The effects of the invasive mussel, Limnoperna fortunei, on associated fauna in South American freshwaters: importance of physical structure and food supply. Fundamental and Applied Limnology. Archiv für Hydrobiologie, 2008, 173(2), 135-144. http://dx.doi.org/10.1127/1863-9135/2008/01730135 .

SAX, D.F., GAINES, S.D. and STACHOWICZ, J.J. Species invasions: insights into ecology, evolution and biogeography. Sunderland: Sinauer Associates, Inc. Publishers, 2005, 480 p.

SILVA, C.V. and HENRY, R. Aquatic macroinvertebrates associated with Eichhornia azurea (Swartz) Kunth and relationships with abiotic factors in marginal lentic ecosystems (São Paulo, Brazil). Brazilian Journal of Biology = Revista Brasileira de Biologia, 2013, 73(1), 149-162. http://dx.doi.org/10.1590/S151969842013000100016. PMid:23644797.

SIMBERLOFF, D. and VON HOLLE, B. Positive interactions of nonindigenous species: invasional meltdown? Biological Invasions, 1999, 1(1), 21-32. http://dx.doi.org/10.1023/A:1010086329619.

SOARES, M.F., PEREIRA, D., SANTOS, C.P., MANSUR, M.C., PIRES, M., BREINTENBACH, J.O. and GRESPAN, C. Toxicidade do sulfato de cobre ao mexilhão dourado, Limnoperna fortunei (Dunker, 1857), em água bruta. Journal of the Brazilian Society of Ecotoxicology, 2009, 4(1-3), 37-48. http://dx.doi.org/10.5132/jbse.2009.01.006.

STACHOWICZ, J. and TILMAN, D. Species invasions and the relationships between species diversity, community saturation, and ecosystem functioning. In D.F. SAX, J.J. STACHOWICZ and S.D. GAINES, eds. Species invasions: insights into ecology, evolution and biogeography. Sunderland: Sinauer Associates, Inc. Publishers, 2005, pp. 41-64.

STRAYER, D.L. and SMITH, L.C. The zoobenthos of the freshwater tidal Hudson River and its response to the zebra mussel (Dreissena polymorpha) invasion. Archive fur Hydrobiologie, Supplements, 2001, 139(1), 1-52.

STRAYER, D.L., CID, N. and MALCOM, H.M. Longterm changes in a population of an invasive bivalve and its effects. Oecologia, 2011, 165(4), 1063-1072. http://dx.doi.org/10.1007/s00442-010-1792-0. PMid:20922431.

STRIPARI, N.L. and HENRY, R. The invertebrate colonization during decomposition of Eichhornia azurea Kunth in a lateral lake in the mouth zone of Paranapanema River into Jurumirim Reservoir (Sao Paulo, Brazil). Brazilian Journal of Biology $=$ Revista Brasileira de Biologia, 2002, 62(2), 293-310. http://
dx.doi.org/10.1590/S1519-69842002000200014. PMid:12494917.

SYLVESTER, F., BOLTOVSKOY, D. and CATALDO, D. The invasive bivalve Limnoperna fortunei enhances benthic invertebrate densities in South American floodplanis rivers. Hydrobiologia, 2007a, 589(1), 1527. http://dx.doi.org/10.1007/s10750-007-0708-4.

SYLVESTER, F., BOLTOVSKOY, D. and CATALDO, D.H. Fast response of freshwater consumers to a new trophic resource: predation on the recently introduced Asian bivalve Limnoperna fortunei in the lower Parana River, South America. Austral Ecology, 2007b, 32(4), 403-415. http://dx.doi.org/10.1111/ j.1442-9993.2007.01707.x.

THOMAZ, S.M., BINI, L.M. and BOZELLI, R.L. Floods increase similarity among aquatic habitats in river-floodplain systems. Hydrobiologia, 2007, 579(1), 1-13. http://dx.doi.org/10.1007/s10750006-0285-y.

UHDE, V., MASSOLI, E.V. and CALLIL, C.T. Efeito do macrofouling sobre a comunidade de invertebrados aqáticos. In M.C.D. MANSUR, C.P. SANTOS, D. PEREIRA, I.C.P. PAZ, M.L.L. ZURITA, M.T.R. RODRIGUEZ, M.V. NEHRKE and P.E.A. BERGONCI, orgs. Guia prático: moluscos límnicos invasores do Brasil: biologia, prevenção e controle. Porto Alegre: Redes Editora, 2012, pp. 235-241.

WALKER, B.H. Biological diversity and ecological redundancy. Conservation Biology, 1992, 6(1), 18-23. http://dx.doi.org/10.1046/j.15231739.1992.610018.x.

WANTZEN, K.M., DRAGO, E. and SILVA, C.J. Aquatic habitats of the Upper Paraguay RiverFloodplain-System and parts of the Pantanal (Brazil). Ecohydrology and Hydrobiologia, 2005, 6(2), 107-126.

WEATHERHEAD, M.A. and JAMES, M.R. Distribution of macroinvertebrates in relation to physical and biological variables in the littoral zone of nine New Zealand lakes. Hydrobiologia, 2001, 462(1), 115-129. http://dx.doi.org/10.1023/A:1013178016080.

WIGGINS, B.G. Larvae of the north american caddsfly genera (Trichoptera). 3rd ed. Toronto: University of Toronto Press, 2000, 455 p.

WIGGINS, G.B., MACKAY, R.J. and SMITH, I.M. Evolutionary and ecological strategies of animals in annual temporary pools. Archive fur Hydrobiologie, Supplements, 1980, 58, p. 97-206.

Received: 11 February 2015 Accepted: 02 December 2015 